\title{
Kajian Kesesuaian Lahan Ekowisata Mangrove Di Desa Arakan Kabupaten Minahasa Selatan Sulawesi Utara
}

\author{
( Study Of Land Suitability For Mangrove Ecotourism In Arakan Village, Minahasa \\ Selatan District, North Sulawesi )
}

\author{
Angelitha O.T Iskandar $^{1^{\star}}$, Joshian N.W. Schaduw ${ }^{1}$, Natalie D.C. \\ Rumampuk $^{1}$, Calvyn F.A. Sondak ${ }^{1}$, Veibe Warouw ${ }^{1}$, Ari Rondonuwu² \\ 1. Program Studi Ilmu Kelautan, Fakultas Perikanan dan Ilmu Kelautan, Universitas Sam \\ Ratulangi, Manado. \\ *e-mail : angeliskandar5@gmail.com
}

The purpose of this study was to determine community structure, mangrove canopy cover and land suitability of mangrove ecotourism. This study used the line transect method for mangrove community structure, interviews for questionnaires and hemispherical photography for the percentage of mangrove cover. The results of the study on mangrove community structure showed that The highest important value index is found in transect 3 , namely $R$. stylosa with value of 292,935 and the lowest on transect 3 is A. officinalis with a value of 7.065. For the suitability of mangrove ecotourism land shows that all transects belong to the suitable category with value of $55.74 \%$ on transect $1,65.57 \%$ on transect $2,68.85 \%$ on transect 3 , $63.93 \%$ on transect 4 and $68.85 \%$ on transect 5.

Keywords: Mangrove, Ecotourism, Arakan Village.

Tujuan dari penelitian ini adalah untuk mengetahui struktur komunitas, tutupan kanopi mangrove dan kesesuaian lahan ekowisata mangrove. Penelitian ini menggunakan metode line transek terhadap struktur komunitas mangrove, wawancara untuk kuisioner dan hemispherical photography untuk persentase tutupan mangrove. Hasil penelitian struktur komunitas mangrove yaitu indeks nilai penting tertinggi terdapat pada transek 3 jenis R.stylosa 292.935 dan terendah pada transek 3 jenis A.officinalis 7.065. Untuk kesesuaian lahan ekowisata mangrove bahwa pada semua transek masuk kategori sesuai dengan nilai kesesuaian transek $155.74 \%$, transek 2 nilai $65.57 \%$, transek 3 nilai $68.85 \%$, transek 4 nilai $63.93 \%$ dan transek 5 nilai $68.85 \%$.

Kata kunci: Mangrove, Ekowisata, Desa Arakan.

\section{PENDAHULUAN}

Hutan mangrove adalah tipe hutan yang khas terdapat di sepanjang pantai atau muara sungai yang dipengaruhi oleh pasang surut air laut. Mangrove tumbuh pada pantai yang terlindung atau pantai yang datar, biasanya di sepanjang sisi pulau yang terlindung dari angin atau di belakang terumbu karang di lepas pantai yang terlindung (Nybakken, 1992). Mangrove juga merupakan kelompok tumbuhan yang dapat tumbuh dengan baik pada kawasan pasang surut di daerah tropis dan subtropis (LIPI, 2014) dan mampu beradaptasi dengan lingkungan yang ekstrim baik suhu yang tinggi, sedimentasi tinggi, salinitas tinggi, pasang surut ekstrim, serta substrat yang kaya oksigen dan tanpa oksigen (Dharmawan \& Pramudji, 2014).

Pembangunan wilayah pesisir dan laut secara berkelanjutan merupakan kebijakan penting Kementrian Kelautan dan Perikanan. Kebijakan tersebut didasarkan pada pemikiran bahwa wilayah pesisir dan laut secara ekologis dan ekonomis potensial untuk dikembangkan dan dimanfaatkan untuk kesejahteraan masyarakat. Pemanfaatan ekosistem mangrove untuk konsep wisata (ekowisata) sejalan dengan pergeseran minat wisatawan dari old tourism yaitu wisatawan yang hanya datang melakukan wisata saja tanpa ada unsur pendidikan dan konservasi menjadi new tourism yaitu 
wisatawan yang datang untuk melakukan wisata yang di dalamnya ada unsur pendidikan dan konservasi (Tuwo, 2011).

Secara geografis Taman Nasional

Bunaken ini terletak di Provinsi Sulawesi Utara dengan luas kawasan $89.065 \mathrm{Ha}$, yang dibagi menjadi dua bagian, yaitu bagian utara dan bagian selatan. Bagian Utara kepulauan meliputi Pulau Bunaken, Pulau Manado Tua, Pulau Siladen, Pulau Mantehage, Pulau Nain, dan daerah bagian daratan pesisir utara yaitu desa Molas, desa Meras, desa Tongkaina, desa Tiwoho, sedangkan bagian Selatan mulai dari desa Poopoh sampai ke desa Popareng (Arakan - Wawontulap) (Metha, 1999). Desa Arakan merupakan desa nelayan dengan luas desa 18,2 ha. 11,2 ha merupakan pemukiman, dan 7 ha merupakan hutan mangrove (Sumual, 2016).

Tujuan dari penelitian ini untuk menganalisis struktur komunitas mangrove yang meliputi kerapatan jenis, kerapatan relatif jenis, frekuensi jenis, frekuensi relatif jenis, penutupan jenis, penutupan relatif jenis, indeks nilai penting, indeks keanekaragaman jenis, dan indeks kemerataan jenis serta menghitung persentase tutupan kanopi mangrove dan Mengkaji kesesuaian lahan ekowisata mangrove. Sedangkan manfaatnya Memperluas wawasan dan sekaligus memperoleh pengetahuan empirik mengenai struktur komunitas mangrove, tutupan kanopi mangrove dan kondisi ekologis dari hutan mangrove Desa Arakan serta dapat dijadikan acuan bagi upaya pengembangan ekowisata di Sulawesi Utara.

\section{METODE PENELITIAN}

\section{Waktu dan Tempat Penelitian}

Penelitian dilakukan di Desa Arakan, Kecamatan Tatapaan, Kabupaten Minahasa Selatan. Pengambilan data di lapangan dilakukan pada bulan Desember 2018. Data diambil meliputi keterwakilan tempat yang berjumlah 5 transek dimana transek 1 berada dekat tempat pembuatan perahu kemudian transek 5 berada dekat sungai dan transek 2,3,4 berada di antara transek ke 1 dan 5 .

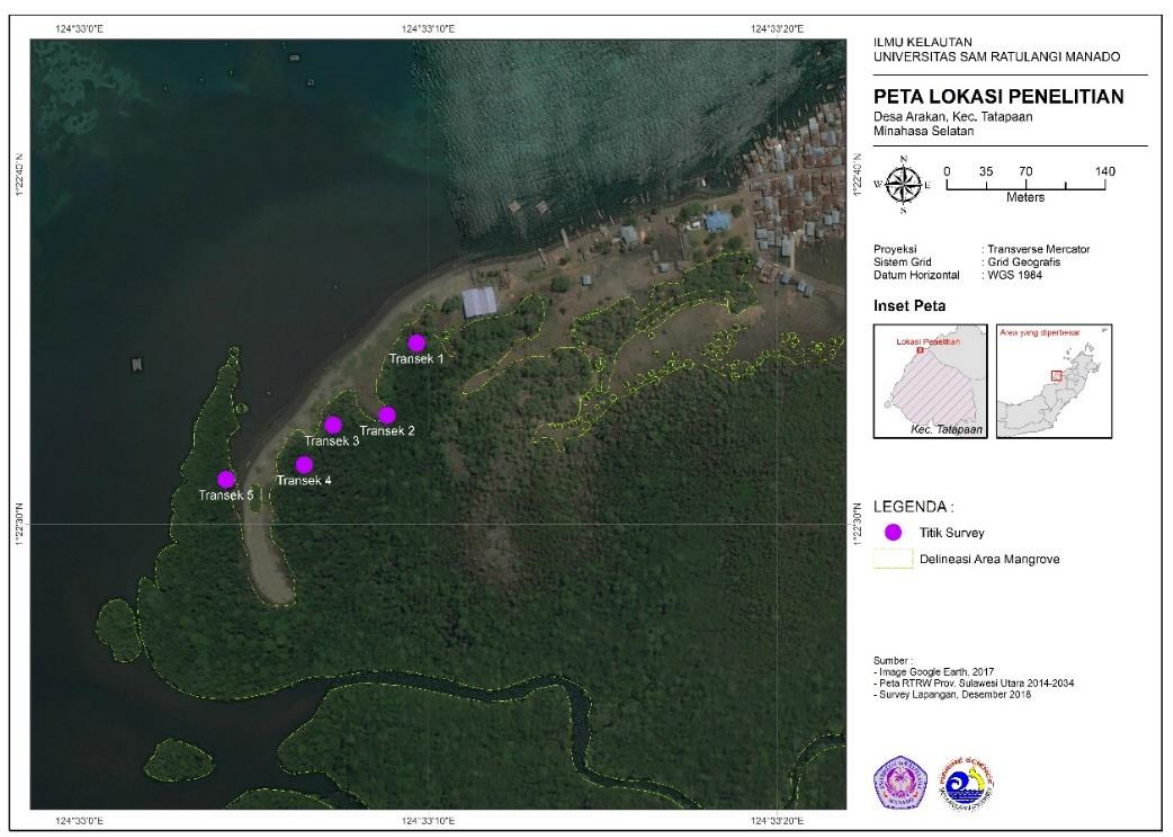

Gambar 1. Peta Lokasi Penelitian 


\section{Alat dan Bahan}

Tabel 1. Alat dan bahan penelitian

\begin{tabular}{lll} 
No & Alat dan Bahan & Kegunaan \\
\hline 1 & Bahan indentifikasi mangrove & Pedoman jenis - jenis mangrove \\
2 & Tali Rafia & Membentuk transek wilayah \\
3 & Kamera handphone & Dokumentasi \\
4 & Alat tulis menulis & Mencatat data yang diambil \\
5 & Handphone ( Aplikasi $\quad$ Google & Merekam titik koordinat \\
6 & Earth) & Pengukuran untuk transek kuadran \\
7 & Meteran rol & Mengukur keliling batang pohon \\
8 & Meteran jahit & Persepsi masyarakat \\
\hline
\end{tabular}

\section{Teknik Penelitian}

Teknik yang digunakan dalam kegiatan penelitian ini adalah survey lapangan, yaitu pengamatan secara langsung di lapangan terhadap kondisi ekosistem mangrove. Teknik pengamatan \& pengukuran di lapangan dalam mengetahui struktur komunitas mangrove dan kesesuaian lahan ekowisata mangrove yaitu dengan menggunakan metode line transect dan kuisioner. Serta pengambilan gambar dalam mengetahui persentase tutupan mangrove dengan menggunakan metode hemisperichal photography.

Metode line transect dilakukan dengan cara membuat garis tegak lurus pantai ke arah darat dengan membuat petakan atau plot-plot (Cox, 1969 dalam Abrar dkk., 2014). Selanjutnya, metode hemisperichal photography adalah teknik untuk karakteristik kanopi dengan menggunakan foto-foto dalam memperkirakan radiasi matahari dan ciri tanaman melalui lensa pandang jauh (Anderson, 1964).

\section{Analisis Kesesuaian Ekologis}

Kegiatan wisata yang dikembangkan hendaknya disesuaikan dengan potensi sumberdaya. Setiap kegiatan wisata mempunyai persyaratan sumberdaya dan lingkungan yang sesuai objek wisata yang dikembangkan. Rumus yang digunakan untuk kesesuaian wisata pantai dan wisata bahari adalah (Yulianda, 2007):

$$
\text { IKW }=\sum \mathrm{Ni} / \mathrm{nmax} \times 100 \%
$$

$$
\begin{aligned}
\text { Dimana: } & \\
\mathrm{IKW}= & \text { Indeks kesesuaian ekosistem } \\
& \text { untuk wisata mangrove } \\
\mathrm{Ni}= & \text { Nilai parameter ke-i (Bobot } \mathrm{x} \\
& \text { Skor) } \\
\mathrm{Nmax}= & \text { Nilai maksimum dari suatu } \\
& \text { kategori wisata }
\end{aligned}
$$


Tabel 2. Matriks kesesuaian lahan untuk wisata pantai kategori wisata mangrove

\begin{tabular}{|c|c|c|c|c|c|c|c|c|c|c|}
\hline $\begin{array}{l}N \\
0\end{array}$ & Parameter & $\begin{array}{l}B \\
0 \\
b \\
0 \\
t\end{array}$ & Kategori baik & Skor & $\begin{array}{l}\text { Kategori } \\
\text { cukup baik }\end{array}$ & Skor & $\begin{array}{l}\text { Kategori } \\
\text { cukup } \\
\text { buruk }\end{array}$ & Skor & $\begin{array}{l}\text { Kategori } \\
\text { Buruk }\end{array}$ & Skor \\
\hline 1. & $\begin{array}{l}\text { Tutupan } \\
\text { Kanopi (m) }\end{array}$ & 5 & $>75 \%$ & 3 & $>50-74.9 \%$ & 2 & $5-24.9 \%$ & 1 & $<5$ & 0 \\
\hline 2. & $\begin{array}{l}\text { Kerapatan } \\
\text { Mangrove } \\
(100 \mathrm{~m})\end{array}$ & 3 & $>15-25$ & 3 & $>10-15$ & 2 & $5-10$ & 1 & $<5$ & 0 \\
\hline 3. & $\begin{array}{l}\text { Jenis } \\
\text { Mangrove }\end{array}$ & 3 & $>5$ & 3 & $3-5$ & 2 & $1-2$ & 1 & 0 & 0 \\
\hline 4. & $\begin{array}{l}\text { Pasang } \\
\text { Surut (m) }\end{array}$ & 1 & $0-1$ & 3 & $>1-2$ & 2 & $>2-5$ & 1 & $>5$ & 0 \\
\hline 5. & $\begin{array}{l}\text { Obyek } \\
\text { biota }\end{array}$ & 1 & $\begin{array}{l}\text { Ikan, udang, } \\
\text { kepiting, } \\
\text { moluska,reptil, } \\
\text { burung }\end{array}$ & 3 & $\begin{array}{c}\text { Ikan, } \\
\text { udang, } \\
\text { kepiting, } \\
\text { moluska }\end{array}$ & 2 & $\begin{array}{c}\text { Ikan, } \\
\text { Moluska }\end{array}$ & 1 & $\begin{array}{l}\text { Salah } \\
\text { satu biota } \\
\text { air }\end{array}$ & 0 \\
\hline 6. & Keunikan & 3 & Ada keunikan & 3 & Sedikit & 2 & $\begin{array}{l}\text { Sangat } \\
\text { Sedikit }\end{array}$ & 1 & $\begin{array}{l}\text { Tidak } \\
\text { Ada }\end{array}$ & 0 \\
\hline 7. & Keaslian & 3 & $\begin{array}{l}\text { Kondisi masih } \\
\text { alami }\end{array}$ & 3 & $\begin{array}{c}\text { Ada } \\
\text { perubahan }\end{array}$ & 2 & $\begin{array}{l}\text { Banyak } \\
\text { Perubahan }\end{array}$ & 1 & $\begin{array}{l}\text { Sangat } \\
\text { Banyak }\end{array}$ & 0 \\
\hline 8. & $\begin{array}{l}\text { Biota } \\
\text { berbahaya }\end{array}$ & 2 & $\begin{array}{l}\text { Tidak ada } \\
\text { biota } \\
\text { berbahaya }\end{array}$ & 2 & $<2$ & 1 & $<5$ & 0 & $<8$ & 0 \\
\hline
\end{tabular}

\section{HASIL DAN PEMBAHASAN}

\section{Struktur Komunitas Mangrove}

\section{Kerapatan jenis dan Kerapatan relatif} jenis

Berdasarkan penelitian yang dilakukan hasil yang didapatkan kerapatan jenis tertinggi pada transek 3 jenis R.stylosa $0.710 \mathrm{ind} / \mathrm{m}^{2}$ relatifnya $97.26 \%$, terendah pada transek 1 jenis A.officinalis dan B.gymnorizha 0.010 ind $/ \mathrm{m}^{2}$ relatifnya $3.70 \%$ dan transek 4 jenis A.officinalis $0.010 \mathrm{ind} / \mathrm{m}^{2}$ relatifnya $3.70 \%$ dan transek 5 jenis B.sexangula $0.010 \mathrm{ind} / \mathrm{m}^{2}$ relatifnya $2.86 \%$. Tingginya nilai kerapatan jenis ditentukan oleh banyaknya jumlah individu, begitu pula sebaliknya jika jumlah individunya sedikit maka nilai kerapatannya rendah. Kerapatan jenis tertinggi disebabkan oleh subsrat yang cocok, dan kemampuan beradaptasi dengan kondisi lingkungan (Agustini $d k k$., 2016). Semakin rapat suatu ekosistem mangrove akan semakin baik dalam hal mereduksi gelombang dan menahan sedimen ataupun sampah dari daratan, akan tetapi hal ini juga akan berdampak buruk bagi pertumbuhan dan regenerasi mangrove. Minimnya penyinaran matahari akan memperlambat proses fotosintesis yang membuat semai ataupun tumbuhan pancang sulit untuk berkembang (Schaduw, 2016). 
Tabel 3. Kerapatan Jenis (Di)

\begin{tabular}{clllll}
\hline \multicolumn{6}{c}{ Kerapatan Jenis (Di) } \\
\hline Jenis & T1 & T2 & T3 & T4 & T5 \\
\hline A. Officinalis & 0.010 & 0.030 & 0.020 & 0.010 & \\
R. Stylosa & 0.250 & 0.570 & 0.710 & 0.230 & 0.320 \\
S. Alba & & 0.020 & & & \\
B. Sexangula & & & & 0.030 & 0.010 \\
B.Gymnorizha & 0.010 & & & & 0.020 \\
\hline
\end{tabular}

Tabel 4. Kerapatan Relatif Jenis (RDi)

\begin{tabular}{cccccc}
\hline \multicolumn{7}{c}{ Kerapatan Relatif Jenis (RDi) } \\
\hline Jenis & $\mathrm{T} 1$ & $\mathrm{~T} 2$ & $\mathrm{~T} 3$ & $\mathrm{~T} 4$ & $\mathrm{~T}$ \\
\hline A. officinalis & 3.70 & 4.84 & 2.74 & 3.70 & \\
R. stylosa & 92.59 & 91.94 & 97.26 & 85.19 & 91.43 \\
S. alba & & 3.23 & & & \\
B.sexangula & & & & 11.11 & 2.86 \\
B.gymnorizha & 3.70 & & & & 5.71 \\
\hline
\end{tabular}

Nilai Tertinggi

Nilai Terendah

Tabel 5. Frekuensi Jenis (Fi)

\begin{tabular}{ccccccc}
\hline \multicolumn{7}{c}{ Frekuensi Jenis (Fi) } \\
\hline Jenis & T1 & T2 & T3 & T4 & T5 \\
\hline A. Officinalis & 0.333 & 1.000 & 0.667 & 0.333 & \\
R. Stylosa & 8.333 & 19.000 & 23.667 & 7.667 & 10.667 \\
S. Alba & & 0.667 & & & \\
B.Sexangula & & & & 1.000 & 0.333 \\
B. Gymnorizha & 0.333 & & & & 0.667 \\
\hline
\end{tabular}

\section{Frekuensi jenis dan Frekuensi relatif jenis}

Nilai frekuensi jenis tertinggi transek 3 jenis R.stylosa 23.667 relatifnya $97.26 \%$ dan frekuensi terendah transek 1 jenis A.officinalis dan B.gymnorizha 0.333 relatifnya 3.70 . Transek 4 A.officinalis 0.333 relatifnya 3.70 dan transek 5 jenis B. sexangula 0.333 relatifnya $2.86 \%$.
Secara keseluruhan jenis Rhizophora stylosa ditemukan pada setiap plot/petak pengamatan. $\mathrm{Hal}$ ini menunjukan bahwa jenis ini memiliki penyebaran jenis dan keberadaan yang lebih tinggi jika dibandingkan dengan jenis yang lainnya. Menurut Poedjirahajoe, 1966 dalam Rusydi, dkk 2015 substrat jenis lempung berpasir atau berlumpur memang merupakan substrat yang sangat 
cocok untuk tempat tumbuhnya jenis

Rhizophora sp.

Tabel 6. Frekuensi Relatif Jenis (RFi)

\begin{tabular}{cccccc}
\hline \multicolumn{7}{c}{ Frekuensi Relatif Jenis (RFi) } \\
\hline Jenis & T1 & T2 & T3 & T4 & T5 \\
\hline A. officinalis & 3.70 & 4.84 & 2.74 & 3.70 & \\
R. stylosa & 92.59 & 91.94 & 97.26 & 85.19 & 91.43 \\
S. alba & & 3.23 & & & \\
B. sexangula & & & & 11.11 & 2.86 \\
B.gymnorizha & 3.70 & & & & 5.71 \\
\hline
\end{tabular}

Nertinggi

Nilai Terendah

Penutupan jenis dan relatif jenis

Nilai penutupan jenis tertinggi pada transek 5 jenis $R$. stylosa 20.075 relatifnya $69.02 \%$. Sedangkan penutupan jenis terendah transek 3 jenis A.officinalis 0.283

Tabel 7. Penutupan Jenis (Ci) relatifnya $1.59 \%$. Sofian dkk., (2012) menyatakan bahwa kondisi hutan mangrove yang berhadapan langsung dengan laut mendapatkan pasang surut air

\begin{tabular}{cccccc}
\hline \multicolumn{7}{c}{ Penutupan Jenis (Ci) } \\
\hline Jenis & T1 & T2 & T3 & T4 & T5 \\
\hline A. officinalis & 1.917 & 1.384 & 0.283 & 0.344 & \\
R. stylosa & 10.550 & 11.894 & 17.561 & 7.981 & 20.075 \\
S. alba & & 1.028 & & & \\
B. sexangula & & & & 0.906 & 2.395 \\
B.gymnorizha & 1.699 & & & & 6.616 \\
\hline
\end{tabular}

Tabel 8. Penutupan Relatif Jenis (RCi)

Penutupan Relatif Jenis (RCi)

Jenis

A. officinalis

R. stylosa

S. alba

$B$. sexangula

B.gymnorizha
T1

13.54

74.47

Nilai Tertinggi

Nilai Terendah

11.99
T2

T3

9.67

1.59

T4

T5

83.14

98.41

3.73

7.19

86.46

69.02

9.82

22.75 
Tabel 9. Indeks Nilai Penting (INP)

\begin{tabular}{cccccc}
\hline \multicolumn{5}{c}{ Indeks Nilai Penting } \\
\hline Jenis & T1 & T2 & T3 & T4 & T5 \\
\hline A. Officinalis & 20.943 & 19.350 & 7.065 & 11.134 & \\
R. Stylosa & 259.659 & 267.012 & 292.935 & 256.828 & 251.875 \\
S. Alba & & 13.638 & & & \\
B. Sexangula & & & & 32.038 & 13.949 \\
B. Gymnorizha & 19.398 & & & & 34.176 \\
\hline
\end{tabular}

Tabel 10. Indeks Keanekaragaman Jenis \& Indeks Kemerataan Jenis

Indeks Keanekaragaman \& Kemerataan

\begin{tabular}{cccccc}
\hline Nilai & T1 & T2 & T3 & T4 & T5 \\
\hline$H^{\prime}$ & 0.32 & 0.33 & 0.13 & 0.50 & 0.35 \\
E & 0.29 & 0.30 & 0.18 & 0.46 & 0.32 \\
\hline
\end{tabular}

Nilai Tertinggi

Nilai Terendah

laut yang sangat mendukung jenis tersebut untuk tumbuh. Selanjutnya Faktor yang mempengaruhi rendahnya nilai penutupan jenis karena adanya kondisi mangrove yang heterogen. Menurut Raymond dkk., (2010), semakin heterogen jenis mangrove dalam suatu komunitas maka peranannya terbagi-bagi dan besarnya indeks semakin bervariasi.

\section{Indeks Nilai Penting (INP)}

Indeks Nilai Penting tertinggi yaitu pada transek 3 jenis R.stylosa 292.935 dan terendah transek 3 jenis A.officinalis 7.065. Dari keseluruhan transek hanya 1 jenis mangrove yang memiliki INP tertinggi dan tersebar di semua transek yaitu Rhizophora stylosa jenis ini memiliki peran cukup penting dalam lingkungan pesisir Desa Arakan. Indriyanto (2006) berpendapat bahwa spesies-spesies yang dominan dalam suatu komunitas tumbuhan

memiliki indeks nilai penting yang tinggi, sehingga spesies yang paling dominan memiliki indeks nilai penting yang paling besar. Selanjutnya Raymond dkk., (2010) menambahkan bahwa jenis yang memperoleh INP tinggi berarti mempunyai nilai kumulatif penguasaan yang lebih besar dan lebih menguasai habitatnya. Jenis ini lebih unggul dalam memanfaatkan sumberdaya atau lebih dapat menyesuaikan diri dengan lingkungan setempat.

\section{Indeks Keanekaragaman Jenis \& Indeks Kemerataan Jenis}

Nilai indeks keanekaragaman jenis $\left(\mathrm{H}^{\prime}\right)$ tertinggi pada transek 40.50 dan terendah pada transek 30.13 . Nilai Indeks kemerataan jenis $(E)$ tertinggi transek 4 0.46 dan terendah transek 30.18 . Dahuri 2003 dalam Bessie dkk., 2013 menyatakan bahwa keanekaragaman ekosistem mangrove terbentuk karena pola zonasi di mana pola ini berkaitan erat dengan faktor lingkungan, seperti tanah (lumpur, pasir, dan gambut), keterbukaan terhadap hempasan gelombang, salinitas, dan pengaruh pasang surut. Selanjutnya, 
menurut Indriyanto 2006 dalam Anthoni dkk., 2017, keanekaragaman spesies juga dapat digunakan untuk mengukur stabilitas komunitas, yaitu kemampuan suatu komunitas untuk menjaga dirinya tetap stabil.

Tabel 11. Tutupan Mangrove

\section{Tutupan Mangrove}

\begin{tabular}{ccccc}
\hline T1 & T2 & T 3 & T 4 & T 5 \\
$82 \%$ & $72 \%$ & $68 \%$ & $80.91 \%$ & $82 \%$ \\
\hline Tabel 12. Kerapatan & Mangrove & & & \\
\hline \multicolumn{7}{r}{ Kerapatan Mangrove } \\
\hline T1 & T2 & T3 & T4 & T5 \\
\hline 0.09 & 0.21 & 0.24 & 0.09 & 0.12 \\
\hline
\end{tabular}

\section{Kesesuaian Ekologis}

\section{Tutupan Mangrove}

Berdasarkan hasil analisis tutupan kanopi mangrove yang dilakukan dengan metode hemispherical photography di Desa Arakan nilai tutupan kanopi mangrove yang tertinggi dari ke 5 transek, terdapat pada transek 1 \& 5, yaitu $82 \%$ dan terendah pada transek $368 \%$. Dari 5 transek semua dalam kategori baik dengan 3 transek berstatus sangat padat dan 2 transek berstatus sedang. Yang mendominasi dari semua transek adalah sangat padat.

\section{Kerapatan Mangrove}

Kerapatan mangrove tertinggi pada transek $3\left(0.24 \mathrm{ind} / \mathrm{m}^{2}\right)$ berdasarkan matriks kesesuaian lahan wisata mangrove maka transek 3 masuk ke kategori baik. Terendah pada transek 1 dan $4\left(0.09 \mathrm{ind} / \mathrm{m}^{2}\right)$ berdasarkan matriks kesesuaian lahan wisata mangrove maka transek 1 dan 4 masuk ke kategori cukup buruk. Kerapatan vegetasi mangrove yang tinggi menunjukkan bahwa komunitas vegetasi tersebut berada pada kondisi yang tidak mengalami gangguan (Erwin, 2005 dalam Hotden dkk., 2014) dan menggambarkan banyak tegakan pohon yang berada dalam kawasan tersebut (Triyadi $d k k$. 2014).

\section{Jenis Mangrove}

Jenis mangrove pada transek 1 memiliki 3 jenis mangrove yatu Avicennia officinalis, Rhizophora stylosa, Sonneratia alba dimana transek 1 ini berdasarkan matriks kesesuaian lahan wisata mangrove masuk ke kategori cukup baik. Pada transek 2 memiliki 3 jenis mangrove yaitu Avicennia officinalis, Rhizophora stylosa dan Sonneratia alba berdasarkan matriks kesesuaian lahan wisata mangrove maka masuk pada kategori cukup baik. Pada Pada transek 3 memiliki 2 jenis mangrove yaitu Avicennia officinalis, Rhizophora stylosa berdasarkan matriks kesesuaian lahan wisata mangrove maka masuk pada kategori cukup buruk. Pada transek 4 memiliki 3 jenis mangrove yaitu, Avicennia officinalis, Rhizophora stylosa, 
Tabel 13. Jenis - Jenis Mangrove

\begin{tabular}{|c|c|c|c|c|c|c|c|}
\hline \multirow{2}{*}{ Jenis } & \multirow{2}{*}{ Family } & \multirow{2}{*}{ Lokal } & \multicolumn{5}{|c|}{ Transek } \\
\hline & & & 1 & 2 & 3 & 4 & 5 \\
\hline Avicennia officinalis & Acathaceae & Api - Api & * & * & * & * & \\
\hline Rhizophora stylosa & Rhizophoraceae & Lalaro & * & * & * & * & * \\
\hline Sonneratia alba & Lythraceae & Posi-Posi & & * & & & \\
\hline Bruguirea sexangula & Rhizophoraceae & Makurung & & & & * & * \\
\hline Bruguirea gymnorizha & Rhizophoraceae & Makurung & * & & & & * \\
\hline
\end{tabular}

\section{Pasang Surut}

Desa Arakan memiliki pantai yang landai. Berdasarkan data sekunder BMKG Sulut tabel pasang surut pada bulan Desember 2018, pasang air laut tertinggi yaitu $6.4 \mathrm{~m}$ dan surut terendah $1.6 \mathrm{~m}$ dengan hasil $4.8 \mathrm{~m}$ maka, matriks kesesuaian lahan wisata mangrove masuk pada kategori cukup buruk. Pasang surut sangat menentukan zonasi, pertumbuhan dan penyebaran kehidupan mangrove. Lama terjadinya pasang di kawasan mangrove dapat mempengaruhi perubahan salinitas air dimana salinitas meningkat pada saat pasang dan menurun pada saat air laut surut.

\section{Objek Biota}

Untuk objek biota, ditemukan biota kepiting dan moluska pada saat pengambilan data di lapangan sedangkan ikan dan udang berdasarkan dari persepsi masyarakat langsung. Maka matriks kesesuaian lahan wisata mangrove untuk objek biota masuk kategori cukup baik. Mangrove yang mempunyai beragam jenis objek biota mempunyai nilai estetika lebih untuk dinikmati pengunjung ( Yulianda, 2018 ).

\section{Keunikan}

Beberapa parameter pengukuran untuk keunikan suatu kawasan mangrove adalah bentuk perakaran yang khas, adanya zonasi dari pinggir pantai sampai pedalaman, biota yang berasosiasi di mangrove seperti serangga, kepiting, moluska, ikan, udang. Dari kriteria di atas tingkat keunikan pada daerah Arakan menunjukan cukup baik.

\section{Keaslian}

Keaslian kawasan mangrove ditandai dengan kondisi kawasan yang masih alami, dimana belum dimanfaatkan sebagai kayu bakar, bahan bangunan dan belum menggunakan bahan kimia mencegah hama \& penyakit. Hanya saja ada tempat pembuatan perahu yang dimanfaatkan oleh masyarakat. Dengan itu hasil dalam kesesuaian lahan wisata mangrove masuk kategori cukup baik.

\section{Biota Berbahaya}

Untuk dijadikan kawasan ekowisata, lingkungan hutan mangrove tersebut tidak boleh terdapat biota yang berbahaya karena tidak aman dan nyaman untuk para wisatawan berkunjung ke kawasan ekowisata mangrove. Tetapi berdasarkan kuisioner masyarakat bahwa secara keseluruhan kawasan mangrove Desa Arakan kurang dari 5 biota berbahaya, dengan itu dari matriks kesesuaian lahan wisata mangrove masuk kategori cukup buruk. 


\section{Penilaian Kesesuaian Lahan Ekowisata Mangrove Desa Arakan}

Tabel 14. Hasil Penilaian Kesesuaian Lahan Ekowisata Mangrove

\begin{tabular}{|c|c|c|c|c|c|c|c|c|c|c|c|}
\hline \multirow{3}{*}{ Parameter } & \multirow{3}{*}{ Bobot } & \multicolumn{10}{|c|}{ Transek } \\
\hline & & \multicolumn{2}{|c|}{1} & \multicolumn{2}{|c|}{2} & \multicolumn{2}{|c|}{3} & \multicolumn{2}{|c|}{4} & \multicolumn{2}{|c|}{5} \\
\hline & & Skor & Nilai & Skor & Nilai & Skor & Nilai & Skor & Nilai & Skor & Nilai \\
\hline Tutupan Kanopi & 5 & 2 & 10 & 2 & 10 & 3 & 15 & 3 & 15 & 3 & 15 \\
\hline Kerapatan Mangrove & 3 & 1 & 3 & 3 & 9 & 3 & 9 & 1 & 3 & 2 & 6 \\
\hline Jenis Mangrove & 3 & 2 & 6 & 2 & 6 & 1 & 3 & 2 & 6 & 2 & 6 \\
\hline Pasang Surut & 1 & 1 & 1 & 1 & 1 & 1 & 1 & 1 & 1 & 1 & 1 \\
\hline Objek Biota & 1 & 2 & 2 & 2 & 2 & 2 & 2 & 2 & 2 & 2 & 2 \\
\hline Keunikan & 3 & 2 & 6 & 2 & 6 & 2 & 6 & 2 & 6 & 2 & 6 \\
\hline Keaslian & 3 & 2 & 6 & 2 & 6 & 2 & 6 & 2 & 6 & 2 & 6 \\
\hline Biota Berbahaya & 2 & 2 & 4 & 2 & 4 & 2 & 4 & 2 & 4 & 2 & 4 \\
\hline $\begin{array}{r}\text { Juml } \\
\text { Nilai Kese } \\
\text { Kategori Ke }\end{array}$ & $\begin{array}{l}\text { uaian } \\
\text { suaian }\end{array}$ & & $\begin{array}{c}62.30 \% \\
52-77 \% \\
\text { S }\end{array}$ & & $\begin{array}{l}72.13 \% \\
52-77 \% \\
\text { S }\end{array}$ & & $\begin{array}{l}75.41 \% \\
52-77 \% \\
\text { S }\end{array}$ & & $\begin{array}{l}70.49 \% \\
52-77 \% \\
\text { S }\end{array}$ & & $\begin{array}{c}75.41 \% \\
52-77 \% \\
\text { S }\end{array}$ \\
\hline
\end{tabular}

\section{KESIMPULAN \& SARAN}

\section{Kesimpulan}

1. Nilai struktur komunitas mangrove kerapatan jenis tertinggi pada transek ke 1 jenis R.stylosa $0.710 \mathrm{ind} / \mathrm{m}^{2}$ relatifnya $97.26 \%$, terendah pada transek 1 jenis A.officinalis dan B.gymnorizha 0.010 relatifnya $3.70 \%$ dan transek 4 jenis A.officinalis 0.010 ind $/ \mathrm{m}^{2}$ relatifnya $3.70 \%$ dan transek 5 jenis B.sexangula $0.010 \mathrm{ind} / \mathrm{m}^{2}$ relatifnya $2.86 \%$.

2. Frekuensi jenis tertinggi pada transek 3 jenis R.stylosa 23.667 relatifnya $97.26 \%$, terendah pada transek 1 A.officinalis dan B.gymnorizha 0.333 relatifnya $3.70 \%$ dan transek 4 jenis A.officinalis 0.333 relatifnya $3.70 \%$ dan transek 5 jenis B.sexangula 0.333 relatifnya $2.86 \%$.

3. Penutupan jenis tertinggi pada transek 5 jenis R.stylosa 20.075 relatifnya $69.02 \%$ dan terendah jenis A.officinalis 0.283 relatifnya $1.59 \%$. Indeks nilai penting tertinggi pada transek 3 jenis R.stylosa 292.935 dan terendah jenis A.officinalis 7.065 .

4. Indeks keanekaragaman jenis tertinggi pada transek 40.50 dan terendah transek 30.13 dan Indeks kemerataan jenis tertinggi transek 40.46 dan terendah transek 30.18 .
5. Hasil keseluruhan kesesuaian lahan untuk wisata pantai kategori wisata mangrove Desa Arakan masuk pada kategori sesuai.

\section{Saran}

Perlu adanya penelitian yang lebih lanjut mengenai kesesuaian lahan wisata pantai untuk dapat menggali potensi sumberdaya wisata pantai di Desa Arakan serta tetap menjaga dan melestarikan hutan mangrove.

\section{DAFTAR PUSTAKA}

Abrar, M., Giyanto., Siringoringo, R.M. Edrus, I.N., Arbi, U.Y., Sihaloho,H.F.,Salatalohi, A dan Sutiadi. 2014. Laporan Monitoring (Baseline) Kesehatan Ekosistem Terumbu Karang dan Ekosistem Terkait Lainnya. Taman Wisata Perairan Pulau Pieh dan Laut di sekitarnya, Provinsi Sumatera Barat. Pusat Penelitian

Oseanografi. Lembaga IImu Pengetahuan Indonesia. $57 \mathrm{Hal}$.

Anderson, M.C. 1964. Studies of the wood land light climate I. The photographic computation of light condition. Journal of Ecology 52: 27-41. 
Anthoni Annice., Joshian N.W Schaduw., Calvyn F.A Sondak. 2017. Persentase Tutupan dan Struktur Komunitas Mangrove Di Sepanjang Pesisir Taman Nasional Bunaken Bagian Utara. Jurnal Pesisir dan Laut Tropis. Vol 2 No. $1: 13-21$.

Agustini, N. Tri., Ta'aladin, Z dan Purnama, D. 2016. Struktur Komunitas Mangrove Di Desa KahyapuPulau Enggano. Program Studi llmu Kelautan Fakultas Pertanian Universitas Bengkulu, Bengkulu. EISSN:2527-5186 Jurnal Enggano Vol 1 No.1.

Bessie M.D., Joshian. N. Schaduw., Emil Reppie., Markus. T. Lasut. 2013. Community Structure Of Mangrove At Marine Tourism Park Of Kupang Bay, East Nusa Tenggara. Aquatic Science \& Management. 3-9 hal.

Darmadi, M. Wahyudin Lewaru. Khan. 2012. Struktur Komunitas Vegetasi Mangrove Berdasarkan Karakteristik Substrat di Muara Harmin, Desa Cangkring, Kecamatan Cantigi, Kabupaten Indramayu. Jurnal Perikanan dan Kelautan. ISSN: 2088-3137. Vol. 3, No. 3. Halaman: 347-358.

Dharmawan, I.W.E. \& Pramudji. 2014. Panduan Monitoring Status Ekosistem Mangrove.

COREMAP-CTI. Pusat Penelitian Oseanografi. Lembaga IImu Pengetahuan Indonesia. 46 hal.

Hotden., Khairijon., Mayta Novaliza Isda. 2014. Analisis Vegetasi Mangrove Di Ekosistem Mangrove Desa Tapian Nauli I Kecamatan Tapian Nauli Kabupaten Tapanuli Tengah Provinsi Sumatera Utara. JOM FMIPA. Vol 1 No. $2: 1-10$

Indriyanto. 2006. Ekologi Hutan. Jakarta: Penerbit Bumi Aksara.
LIPI, 2014. Kekinian Keanekaragaman Hayati Indonesia 2014. LIPI Pres, anggota Ikapi. Pusat Penelitian Biologi

Metha, A. 1999. Buku Panduan Lapanga Taman Nasional Bunaken. Balai Taman Nasional Bunaken. NRM/EPOIQ Program, September 1999. Rompas R. M. et al. 2008. Pengantar Ilmu Kelautan. Sekretariat Dewan Kelautan Indonesia. Jakarta.

Raymond, G., H. Nurdin., dan Soemarno. 2010. Pengelolaan hutan mangrove berbasis masyarakat di Kecamatan Gending, Probolinggo. Jurnal agritek. Vol 18 No. $2: 186$ 187.

Rusila Noor, Y., M. Khazali, dan I N.N. Suryadiputra. 1999. Panduan Pengenalan Mangrove di Indonesia. PHKA/WI-IP, Bogor.

Rusydi., Ihwan., Suaedin. 2015. Struktur dan Kepadatan Vegetasi Mangrove Di Teluk Kupang. Jurnal Segara. Vol 11 No. 2: 147157.

Sofian A, Harahap dan Marsoedi. 2012. Kondisi dan Manfaat Langsung Ekosistem Hutan Mangrove Desa Penunggul Kecamatan Nguling Kabupaten Pasuruan. Jurnal El-Hayah. Vol 2 No. 2 : 56 63.

Schaduw. N. W. Joshian. 2016. Kondisi Ekologi Mangrove Pulau Bunaken Kota Manado Provinsi Sulawesi Utara. Jurnal LPPM Bidang Sains dan Teknologi. Vol 3 No.2 : 64-74.

Tuwo, A. 2011. Pengelolaan Ekowisata Pesisir dan Laut. Surabaya: Brilian Internasional. Xii + 412 hal. 
Yulianda, F. 2007. Ekowisata bahari sebagai alternatif pemanfaatan sumberdaya pesisir berbasis konservasi. Makalah Seminar Sains 21 Februari 2007. Departemen Manajemen Sumberdaya Perairan, FPIK. IPB.
Yulianda, F. 2018. Buku Panduan Kriteria Penetapan Zona Ekowisata Bahari. Bogor:IPB Press. 
